\title{
On the distribution of decapod crustaceans from the Magellan Biogeographic Province and the Antarctic region*
}

\author{
ENRIQUE E. BOSCHI ${ }^{1,2}$ and MARÍA A. GAVIO ${ }^{3}$ \\ ${ }^{1}$ Consejo Nacional de Investigaciones Científicas y Técnicas (CONICET) \\ ${ }^{2}$ Instituto Nacional de Investigación y Desarrollo Pesquero (INIDEP) \\ ${ }^{3}$ Departamento de Biología. Facultad de Ciencias Exactas y Naturales (UNMdP), Casilla de Correo 175, \\ 7600 Mar del Plata, Argentina. E-mail: eboschi@inidep.edu.ar
}

\begin{abstract}
SUMMARY: The distribution of decapod crustaceans in the southernmost areas of South America and the Antarctic is assessed considering the Magellan Biogeographic Province instead of the antiboreal region. Possible associations between decapod crustaceans from the Magellan Biogeographic Province and those from the Antarctic region are analysed. Species records were assigned to seven geographic regions that were clustered using multivariate analyses based on species presence/absence and Bray-Curtis similarity. The results showed two well-established clusters, one of which included the Pacific and Atlantic areas of the Magellan Province, the southern tip of South America and the Kerguelen Arc islands, with the highest similarity between the southern tip and the Atlantic area. Another cluster was well separated and included the Antarctic and South Georgia with the highest similarity index. Earlier studies and results obtained here suggest that the faunas of southern Chile and southern Argentina are biogeographically related. There is a low level of association among decapod species from the circum-Antarctic region and the Magellan Province.
\end{abstract}

Keywords: decapod crustaceans, Magellan Biogeographic Province, circum-Antarctic distribution.

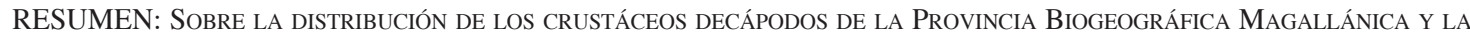
REGIÓN ANTÁRTICA. - Se estudió la distribución de los crustáceos decápodos en las áreas más australes de Sudamérica, considerando la Provincia Biogeográfica Magallánica en lugar de la región antiboreal. Se analizó la posible asociación entre los crustáceos de la Provincia Magallánica y los de la región antártica. Las especies registradas fueron asignadas a siete regiones geográficas, las que fueron agrupadas utilizando análisis de agrupamientos basado en presencia/ausencia de especies. Se utilizó el índice de similitud de Bray- Curtis. Los resultados mostraron dos grupos bien definidos de los cuales uno incluyó las áreas pacífica y atlántica de la Provincia Magallánica, la del extremo más austral de Sudamérica y las islas del Arco de Kerguelen. El otro grupo estuvo separado del anterior e incluyó la Antártida y las Islas Georgias con el índice de similitud más alto. Estudios anteriores y los resultados obtenidos en éste, sugieren que las faunas del sur de Chile y sur de Argentina se encuentran relacionadas. Existe baja asociación entre las especies actuales de crustáceos decápodos con distribución circumantártica y las de la Provincia Magallánica.

Palabras clave: crustáceos decápodos, Provincia Biogeográfica Magallánica, distribución circumantártica.

\section{INTRODUCTION}

Our knowledge on the distribution of decapod crustaceans from the Southern Ocean and Sub-

*Received april 14, 2004. Accepted June 28, 2005. antarctic areas has increased considerably in the past years, and some studies have been concentrating on faunal connections of the Magellan and Antarctic decapod fauna (Arntz et al., 1999; Gorny, 1999; Thatje and Arntz, 2004).

A common feature of previous studies is that the 
Magellan region is referred to as the South American antiboreal region, between the Subtropical and the Antarctic Convergence (Ekman, 1953). Holthuis (1952) identified Chiloé Island in the Pacific Ocean as the northern boundary of the South American antiboreal region. In the Atlantic, the Río de La Plata was the limit considered in other studies. Zarenkov (1968) recognised the Antarctic Convergence as the limit of the Antarctic decapod fauna. Boschi (1979b) proposed using the term "South American Notal" for the southern hemisphere instead of "antiboreal", and recognised that the fauna from southern Chile and southern Argentina are related (Boschi, 2000a).

The distribution and biodiversity of decapods on the continental shelves of North and South America were divided into sixteen biogeographic provinces by Boschi (2000a, b), who defined a province as "part of the neritic zone with a relatively narrow range of temperatures where the fauna shows certain homogeneity". It should be mentioned that species can be present in more than one province. The Maguellan Biogeographic Province extends from northern Chiloé Island on the Eastern Pacific Ocean south to the Maguellan and Tierra del Fuego region through Cape Horn, and reaches the coastal area of the southwestern Atlantic Ocean off the Patagonian region. It includes the Islas Malvinas/Falkland Islands, and ends north at the Península Valdés (Boschi, 2000a, b). The Province extends off the continent at $43^{\circ}-44^{\circ} \mathrm{S}$ stretching north to reach $35^{\circ} \mathrm{S}$ at a distance of 100-150 km from the coast and 60$200 \mathrm{~m}$ water depth. In the southwestern Atlantic, the Argentinean Biogeographic Province includes the coastal waters off Patagonia from $43-44^{\circ} \mathrm{S}$ to $23^{\circ} \mathrm{S}$ (see Boschi, 2000a). Between $43-44^{\circ} \mathrm{S}$ and $35^{\circ} \mathrm{S}$, both provinces occupy the same latitudinal range (see Boschi, 2000a, b; Fig. 1).

The determination of regions in the oceans (Ekman, 1953) and provinces on the continental shelves (Boschi, 2000a) follow oceanographic characteristics, temperature being one of the main determinants in the distribution of crustaceans. However, the distribution of the circum-Antarctic decapod fauna studied by other authors also considered ecological features such as productivity and habitat (Gorny, 1999), and most recently ecological and physiological limits in crustaceans (for a review see Thatje and Arntz, 2004). In studies in which the boundaries of the South American antiboreal region were considered, a number of species were placed in different biogeographic provinces such as the Mag- ellan or the Argentinean. Boschi (2000a) concluded that at that time the number of species present in the Magellan Province was 79, of which 19 were endemic. Since then, new records have been published (Thatje, 2000, 2003, Thatje and Gerdes, 2000).

The aim of this study is to determine whether there is a biogeographic association between decapod crustaceans from the Magellan Biogeographic Province and those from the Antarctic region, and to compare our results with those of previous studies in which species with circum-Antarctic distribution were also considered.

\section{MATERIAL AND METHODS}

The database utilised here includes species from the Magellan Province compiled by Boschi (2000a), and those with circum-Antarctic distribution and new species updated from the literature (Arntz and Gorny, 1991; Arntz et al., 1999; Boschi et al., 1992; Retamal, 2000; Zarenkov, 1968; Gorny, 1999; Kirkwood, 1984; Macpherson, 1988; Thatje and Gerdes, 2000; Thatje, 2000, 2003; Yaldwyn, 1965). The Magellan Province includes species present on both coasts, only in the Pacific or only in the Atlantic. In biogeographic terms, the southernmost boundary reaches Cape Horn, and therefore, species present north of $55^{\circ} \mathrm{S}$ belong to the Magellan Province.

Considering the limits of the Magellan Biogeographic Province and species distribution, for this study we assigned species to the following geographic areas: [1] the Magellan Atlantic (north of $55^{\circ} \mathrm{S}$ ), [2] the Magellan Pacific (north of $55^{\circ} \mathrm{S}$ ), [3] the Southern tip of South America (south of $55^{\circ} \mathrm{S}$ ), [4] the Antarctic (continental shelf and islands off the Antarctic Peninsula), [5] South Georgia, [6] the Kerguelen Arc Islands, and [7] South American deep fauna.

The geographic regions were clustered using PRIMER 5.2 multivariate cluster analysis based on species presence/absence. The Bray-Curtis similarity index was used. South American deep-sea species contained in the species list were not included in the analysis.

\section{RESULTS}

In the Magellan Province (Atlantic and Pacific sides, southern tip and deep species), there is a much 
TABLE 1 - Species list and geographic distribution of decapods in the Magellan Biogeographic Province and the Antarctic region. (MA: Atlantic Magellan, MP: Pacific Magellan, ST: Southern tip of South America, A: Antarctic, SG: South Georgia, K: Kerguelen Arc Islands, DS: South American deep species).

\begin{tabular}{|c|c|c|c|c|c|c|c|c|c|}
\hline Infraorder & Family & Species & MA & MP & ST & A & SG & $\mathrm{K}$ & DS \\
\hline Anomura & $\begin{array}{l}\text { Paguridae } \\
\text { Parapaguridae } \\
\text { Porcellanidae }\end{array}$ & $\begin{array}{l}\text { Uroptychus parvulus } \text { (Henderson, 1885) } \\
\text { Coenobita compressus (H. Milne Edwards, 1837) } \\
\text { Paguristes weddelli (H. Milne Edwards, 1848) } \\
\text { Munida gregaria (Fabricius, 1793) } \\
\text { Munida spinosa (Henderson, 1885) } \\
\text { Munida subrugosa (White, 1847) } \\
\text { Munidopsis aspera (Henderson, 1885) } \\
\text { Emerita analoga (Stimpson, 1857) } \\
\text { Lithodes confundens (Macpherson, 1988) } \\
\text { Lithodes santolla (Molina, 1782) } \\
\text { Lithodes turkayi (Macpherson, 1988) } \\
\text { Lithodes murrayi, Henderson, 1888 } \\
\text { Paralomis aculeatus Henderson, 1888 } \\
\text { Paralomis anamerae (Macpherson, 1988) } \\
\text { Paralomis formosa (Henderson, 1888) } \\
\text { Paralomis granulosa (Jaquinot, 1847) } \\
\text { Paralomis spinosissima (Birstein y Vinogradov, 1972) } \\
\text { Paralomis tuberipes (Macpherson, 1988) } \\
\text { Pagurus comptus (White, 1847) } \\
\text { Propagurus gaudichaudii (H. Milne Edwards, 1836) } \\
\text { Sympagurus dimorphus (Studer, 1882) } \\
\text { Liopetrolisthes mitra (Dana, 1852) } \\
\text { Petrolisthes laevigatus (Guérin, 1835) } \\
\text { Petrolisthes violaceus (Guérin, 1831) }\end{array}$ & $\begin{array}{l}* \\
* \\
* \\
* \\
* \\
* \\
*\end{array}$ & $\begin{array}{l}* \\
* \\
* \\
* \\
* \\
* \\
* \\
* \\
* \\
*\end{array}$ & $\begin{array}{l}* \\
* \\
*\end{array}$ & $*$ & * & $\begin{array}{l}* \\
* \\
*\end{array}$ & \\
\hline Astacidea & Nephropidae & Thymops birsteini (Zarenkov and Semenov, 1972) & $*$ & $*$ & $*$ & & & & $*$ \\
\hline Brachyura & $\begin{array}{l}\text { Atelecyclidae } \\
\text { Bellidae } \\
\text { Cancridae } \\
\text { Corystidae } \\
\text { Epialtidae } \\
\text { Geryonidae } \\
\text { Grapsidae } \\
\text { Hymenosomatidae } \\
\text { Inachidae } \\
\text { Inachoididae } \\
\text { Leucosiidae } \\
\text { Majidae } \\
\text { Pinnotheridae } \\
\text { Pisidae } \\
\text { Portunidae } \\
\text { Xanthidae }\end{array}$ & 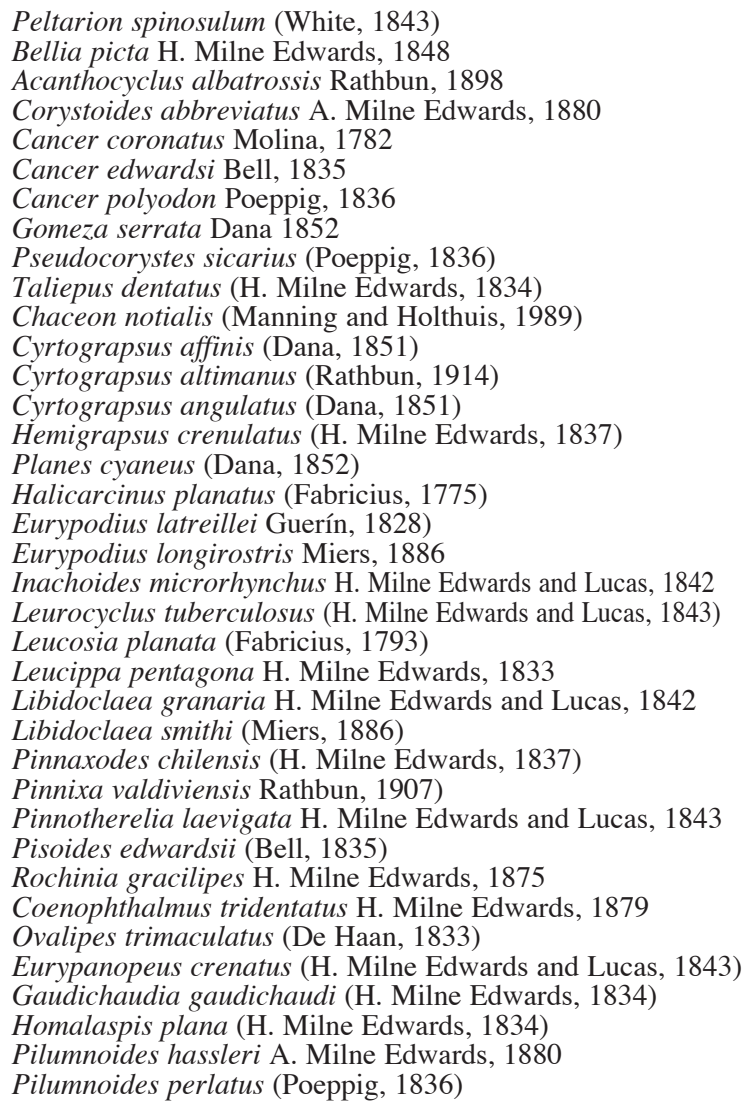 & $\begin{array}{l}* \\
* \\
* \\
* \\
*\end{array}$ & $\begin{array}{l}* \\
* \\
* \\
* \\
* \\
* \\
* \\
* \\
* \\
* \\
* \\
* \\
* \\
* \\
*\end{array}$ & $\begin{array}{l}* \\
*\end{array}$ & & & $*$ & \\
\hline Caridea & $\begin{array}{l}\text { Alpheidae } \\
\text { Campylonotidae }\end{array}$ & $\begin{array}{l}\text { Betaeus truncates Dana, } 1852 \\
\text { Synalpheus spinifrons (H. Milne Edwards, 1837) } \\
\text { Campylonotus semistriatus Bate } 1888 \\
\text { Campylonotus arntzianus Thatje, } 2003 \\
\text { Campylonotus vagans Bate, } 1888 \\
\text { Campylonotus capensis Bate, } 1888\end{array}$ & $\begin{array}{l}* \\
* \\
*\end{array}$ & $\begin{array}{l}* \\
* \\
*\end{array}$ & $*$ & $\begin{array}{l}* \\
*\end{array}$ & $*$ & $*$ & \\
\hline
\end{tabular}


TABLE 1 (Cont.). - Species list and geographic distribution of decapods in the Magellan Biogeographic Province and the Antarctic region. (MA: Atlantic Maguellan, MP: Pacific Maguellan, ST: Southern tip of South America, A: Antarctic, SG: South Georgia, K: Kerguelen Arc Islands, DS: South American deep species).

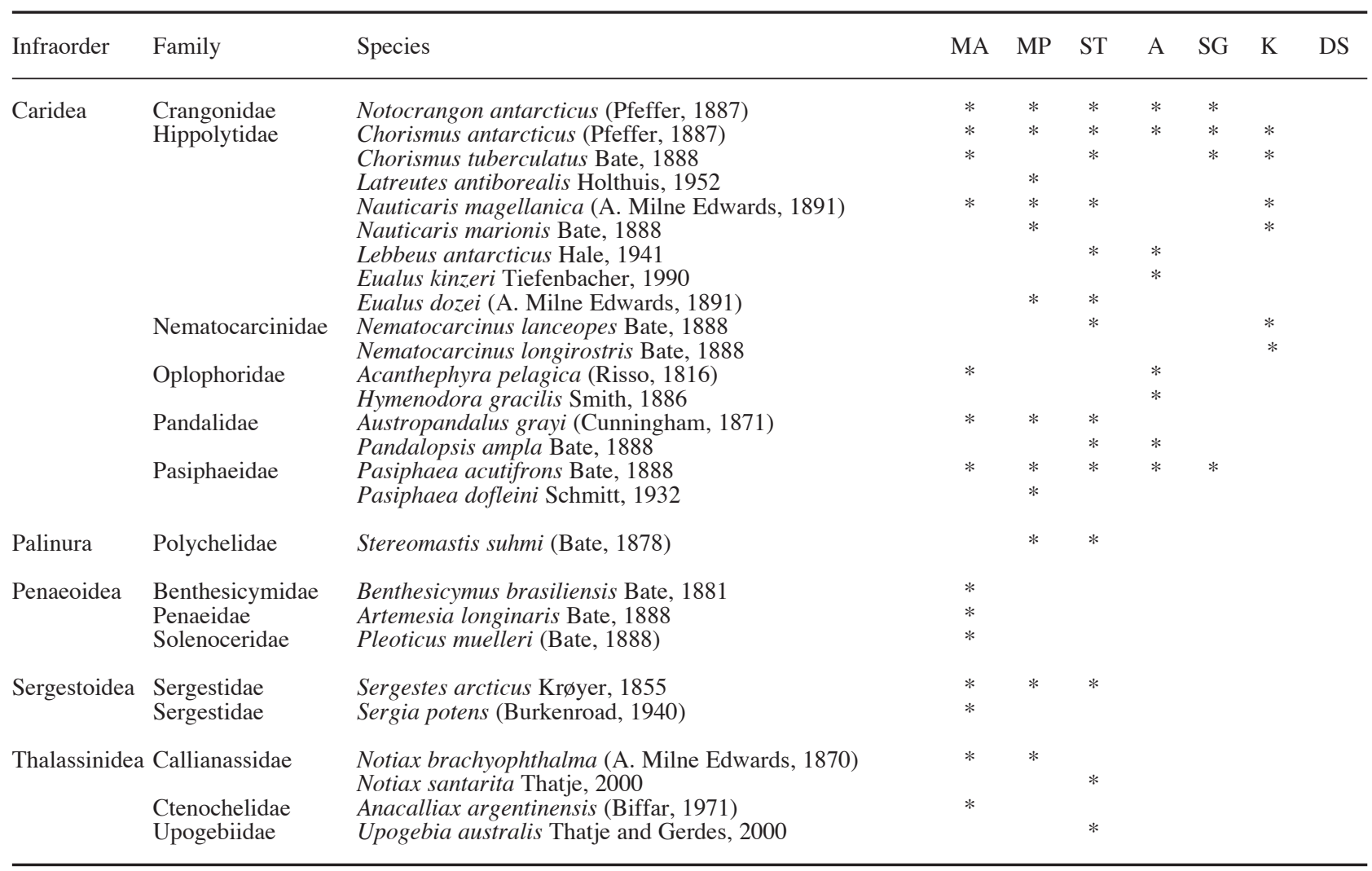

higher number of species than those currently recognised for the Antarctic. The Anomura (22 species), Brachyura (37 species) and Caridea (19 species) are well represented in the Magellan Province (Table 1), whereas the only taxa present in the Antarctic, the Caridea (10 species incl. SG) and Anomura Lithodidae (3 species incl. SG), are low in species numbers. The total number of species cited for the whole study area is 95. In the Magellan Province, 16 species were present only in the Atlantic and 33 only in the Pacific, with 32 present in both oceans (Table 1).

At the southern tip, 32 non-endemic species were recorded that are also present either in the Atlantic or the Pacific area of the Magellan Province north of $55^{\circ} \mathrm{S}$ (Table 1). Four of them, Campylonotus vagans (but see Thatje, 2003), Notocrangon antarcticus, Chorismus antarcticus and Paralomis spinosissima, are also found in the Antarctic and South Georgia. The distribution range of two Antarctic species, Lebbeus antarcticus and Pandalopsis ampla, stretches to the southern tip of South America. Four anomuran species, Munida gregaria, M. subrugosa, M. spinosa and Paralomis spinosissima, and four carideans, Chorismus antarcticus, C. tuberculatus, Nauticaris magellani$c a$, and N. marionis, are found in both the Magellan Province and the Kerguelen Arc.

The dendrogram shows two clusters (A and B) (Fig. 2). Cluster A involves the Pacific and Atlantic areas of the Magellan Province and the southern tip, with the highest similarity index between the southern tip and the Atlantic area. The islands of the Kerguelen Arc are mostly associated with the South American fauna. Cluster B includes the Antarctic and South Georgia, with a high similarity index (Table 2).

\section{DISCUSSION}

The biogeography of crustacean decapods from the Magellan Province and the Antarctic follows different patterns. The distribution of thirteen species overlaps in the Magellan Province and the circumAntarctic area (Table 1). Ten species out of 95 recorded for the study are present in the Antarctic, only five of them also being found in waters off South Georgia, and two of them (Chorismus 


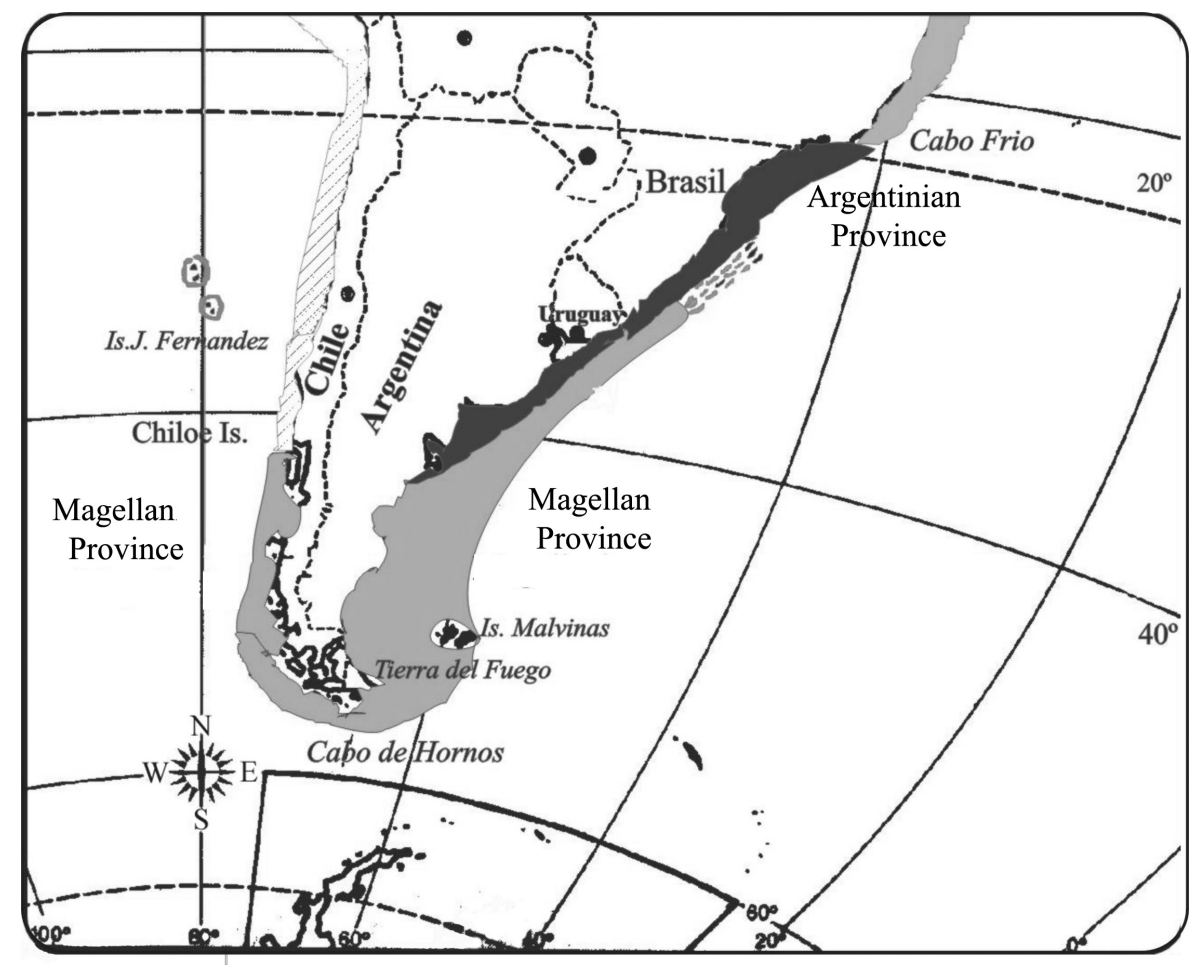

FIG. 1. - Extension of the Magellan Province around the southern tip of South America.

TABLE 2. - Bray-Curtis similarity matrix of geographic regions based on the distribution of decapod species.

\begin{tabular}{lccccc}
\hline & $\begin{array}{c}\text { Magellan } \\
\text { Atlantic }\end{array}$ & $\begin{array}{c}\text { Magellan } \\
\text { Pacific }\end{array}$ & $\begin{array}{c}\text { Southern tip of } \\
\text { S. America }\end{array}$ & Antarctic & South Georgia \\
\hline Magellan Pacific & 56.14 & & & & \\
Southern tip of S. America & 59.25 & 49.48 & 31.11 & 60.00 & 28.57 \\
Antarctic & 19.35 & 10.25 & 30.76 & 22.22 & \\
South Georgia & 25.00 & 11.11 & 43.47 & \\
Kerguelen Is. & 28.57 & 17.72 & & \\
\hline
\end{tabular}

antarcticus and $C$. tuberculatus) in the Kerguelen Arc (Table 1). Halicarcinus planatus is the only brachyuran crab present in the Magellan Province; it has a range that extends to the Kerguelen Arc and the genus is of circum-Antarctic distribution (Gorny, 1999). However, H. planatus has never been recorded at South Georgia (Gorny, 1999), and its presence in the South Orkney Islands, as reported by other authors, is uncertain due to probably mislabelled material (Thatje and Arntz, 2004).

The decapod fauna along the Pacific and Atlantic ocean coasts of the Magellan Province is similar. In terms of species number it is the largest group compared to the Antarctic and circum-Antarctic areas. The numbers presented here are slightly higher than those reported by Boschi (2000a), due to the updated information included in Table 1. Despite the high degree of similarity, the cluster analysis separates the Pacific area from the Atlantic and the southern tip of South America (Fig. 2).

Gorny (1999) studied the biogeography and ecology of the Southern Ocean decapod crustaceans and concluded that brachyurans should be included in the Antarctic decapod fauna. Our results and conclusions differ from those obtained by Gorny in two aspects: 1) concerning the biogeographic regions considered, and 2) with regard to the database used in the analysis. As in this study we considered the limits of the Magellan Biogeographic Province, which are different from those of the Magellan region, the species arrangement changed. For example, Chaceon notialis was included in the antiboreal and temperate regions of Argentina (Gorny, 1999) although it is only present in the Magellan Province 


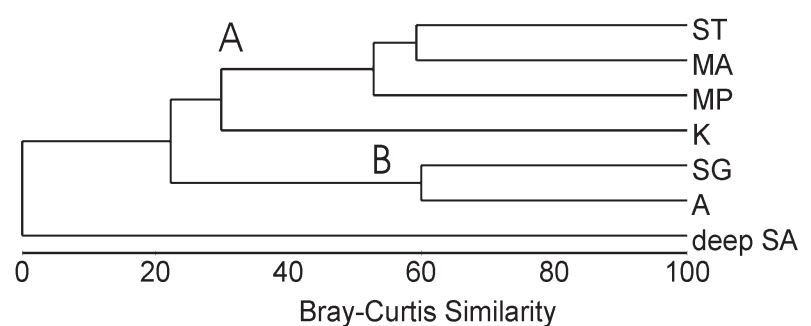

FIG. 2. - Cluster analysis of geographic regions. Cluster A shows a high similarity index between the Magellan Atlantic, the southern tip of South America and the Magellan Pacific. The Kerguelen Arc Islands are associated with the Magellan Province. Cluster B includes South Georgia and the Antarctic. Cluster A and B show great dissimilarity. ST: Southern tip of South America, MA: Magellan Atlantic, MP: Magellan Pacific, K: Kerguelen Arc Islands, SG: South Georgia, A: Antarctic, deep, SA: South American deep species.

(Boschi, 2000a, b). On the other hand, the anomuran Pachycheles chubutensis was included in the antiboreal region (Gorny, 1999), while this species is only present in the Argentinean Province (Boschi 2000a, b). This interpretation of the distribution of species along the Argentinean coast is due to the use of "antiboreal regions" instead of "biogeographic provinces", whose distributional ranges overlap in this case (Boschi, 2000a, b).

Acha et al. (2004) recognised six marine zones that cover all neritic ecosystems of austral South America. The "Patagonian cold estuarine" zone encircles the tip of South America and connects both the Pacific and Atlantic oceans. The authors propose that the southward currents from Chiloé Island, reaching the cold estuarine front of Atlantic Patagonia and the Atlantic shelf-break front, could be a transport system for organisms into the Argentinean Magellan Province (Acha et al., 2004). Several authors (Knox, 1960; Stuardo, 1964; Boschi, 1966, 1976, 1979a, b, 2000a; Boschi et al., 1981, 1992) argue that the faunas of southern Chile and southern Argentina are related. This is confirmed by our study and we conclude that there is little similarity between decapod species from the Antarctic and the Magellan Province, which is obviously the result of the impoverished Antarctic decapod fauna in general (Thatje and Arntz, 2004).

\section{ACKNOWLEDGEMENTS}

We would like to thank José Luis Swidzinsky for the design of the figure and for his help with computer software, and the reviewers who improved the manuscript.

\section{REFERENCES}

Acha, M., H. Mianzan, R. Guerrero, M. Favero and J. Bava. - 2004. Marine fronts at the continental shelves of austral South America. Physical and ecological processes. J. Mar. Syst. 44: 83-105.

Arntz, W.E. and M. Gorny. - 1991. Shrimp (Decapoda, Natantia) occurrence and distribution in the eastern Weddell Sea, Antarctica. Polar Biol., 11: 169-177.

Arntz, W.E., M. Gorny, R. Soto, M. Lardies, M. Retamal and I.S. Wehrtmann. - 1999. Species composition and distribution of decapod crustaceans in the waters off Patagonia and Tierra del Fuego, South America. Sci. Mar. 63(Suppl. 1): 303-314.

Boschi, E.E. - 1966. Preliminary note on the geographic distribution of the decapod crustaceans of the marine waters of Argentina (South West Atlantic Ocean). Symp. Proc. Crustacea. India, 1: 449-456.

Boschi, E.E. - 1976. Nuevos aportes al conocimiento de la distribución geográfica de los crustáceos decápodos del Mar Argentino. Physis, Buenos Aires A, 35(90): 59-68.

Boschi, E.E. - 1979a. Los crustáceos decápodos en las comunidades bentónicas del mar epicontinental argentino. In: Memorias Simposio ecología bentónica y sedimentación de la plataforma continental del Atlántico Sur. UNESCO, Montevideo, Uruguay, 279-290.

Boschi, E.E. - 1979b. Geographic distribution of Argentinean marine decapod crustaceans. Bull. Biol. Soc. Wash. 3: 134-143.

Boschi, E.E. - 2000a. Species of decapod crustaceans and their distribution in the American marine zoogeographic provinces. Rev. Invest. Desarro. Pesq. 13, 7-136.

Boschi, E.E. - 2000b. Biodiversity of marine decapod brachyurans of the Americas. J. Crustacean Biol. 20: 337-342.

Boschi, E.E., K. Fischbach and M.I. Iorio. - 1992. Catálogo ilustrado de los crustáceos estomatópodos y decápodos marinos de Argentina. Frente Marítimo, 10(A): 7-94.

Boschi, E.E., M.I. Iorio and K. Fischbach. - 1981. Distribución y abundancia de los crustáceos decápodos capturados en las campañas de los B/I "Shinkai Maru" y "Walter Herwig" en el Mar Argentino, 1978-1979. Contrib. INIDEP, Mar del Plata, 383: 233-253.

Ekman, S. - 1953. Zoogeography of the sea. Sidgwick and Jackson Ltd., London.

Gorny, M. - 1999. On the biogeography and ecology of the Southern Ocean decapod fauna. Sci. Mar., 63(Suppl. 1): 367-382.

Holthuis, L.B. - 1952. The Crustacea Decapoda Macrura of Chile. Reports of the Lund University Chile Expedition 1948-49, 5. Lunds Univ. Arsskrift N.F., Avd. 2, 47(10): 1-110.

Kirkwood, J. M. 1984. A guide to the Decapoda of the Southern Ocean. ANARE Res. Notes, 11: 1-47.

Knox, G.L. - 1960. Littoral ecology and biogeography of the Southern Oceans. Proc. Roy. Soc. B, 152(949): 577-624.

Macpherson, E. - 1988. Revision of the family Lithodidae Samouelle, 1819 (Crustacea, Decapoda, Anomura) in the Atlantic Ocean. Monogr. Zool. Mar., 2: 9-153.

Retamal, M.A. - 2000. Decápodos de Chile. World Biodiversity Database. CD-ROM Series. Expert Center for Taxonomic Identification ETI Chile. Universidad de Concepción, Chile.

Stuardo, J. - 1964. Distribución de los moluscos marinos litorales en Latinoamérica. Bol. Inst. Biol. Mar. Mar del Plata, 7: 79-91.

Thatje, S. - 2000. Notiax santarita, a new species of the Callianassidae (Decapoda, Thalassinidea) from the Beagle Channel, Southernmost America. Crustaceana, 73(3) 289-299.

Thatje, S. - 2003. Campylonotus arntzianus, a new species of the Campylonotidae (Crustacea: Decapoda: Caridea) from the Scotia Sea (Antarctica). Polar Biol., 26: 242-248.

Thatje, S. and D. Gerdes. - 2000. Upogebia australis, a new species of the Upogebiidae (Crustacea, Decapoda, Thalassinidea) from the Beagle Channel (Magellan region). Mitt. Mus. Nat. Kd. Berlin, Zool. Reihe., 76(2): 231-236.

Thatje, S. and W. Arntz. 2004. Antarctic reptant decapods: more than a myth? Polar Biol., 27: 195-201.

Yaldwyn, J. C. 1965. Antarctic and Subantarctic decapod Crustacea. In: J. Van Mieghem and P. van Oye (eds.), Biogeography and Ecology in the Antarctic, pp. 324-332. W. Junk Publ., The Hague.

Zarenkov, N.A. - 1968. Crustacea Decapoda collected by the Soviet Antarctic expeditions in the Antarctic and antiboreal regions. Biol. Rep. Soviet. Antarct. Exped. (1955-1958) 4: 153-201. 